\title{
Risk Factors of Miopia in Junior High School Students In Denpasar
}

\author{
Putu Indah Budi Apsari ${ }^{1 *}$, I Nengah Kapti ${ }^{1}$, I Made Dharma Putra ${ }^{1}$ \\ ${ }^{1}$ Faculty of Medicine and Health Sciences, Universitas Warmadewa \\ *putuindah51@yahoo.com
}

\begin{abstract}
Prevalence of patient with refractive disorders in Indonesia almost reached $25 \%$ of the population or about 55 million people. Myopia is one of the refractive disorders in the eye. Over the last few decades showed the prevalence of myopia increased and became epidemic of myopia in Asia. Genetic factors, lifestyles, vitamins A, C, D and E are the risk factors which play great roles in the occurrence of myopia. The purpose of this study was to know the risk factors of myopia in junior high school students in Denpasar. This case control study used subject from junior high school students in Denpasar. There were 49 people who has miopia as the case and 49 people without it as the control. Data were collected by direct interviewed using prepared questionnaires, was analyzed using chi square test. The result showed significant correlation between genetic factor and myopia $(\mathrm{p}=0,013 ; \alpha<0,05)$, lifestyles $(\mathrm{p}=0,02$, $\alpha<0,05)$, and vitamins $\mathrm{A}, \mathrm{C}, \mathrm{D}$ and $\mathrm{E}$ consumption ( $\mathrm{p}=0,039 ; \alpha<0,05)$. It is expected that community health care and schools to conduct routine checks, early detection of eye health and educate the lifestyle and vitamin consumption.
\end{abstract}

Keyword: Miopia, Junior High School, Students.

\section{Introduction}

The eye is a very important sense for human life and determines the quality of human life. The global prevalence of refractive disorders is estimated at around 800 million to 2.3 billion. In Indonesia the prevalence of refractive disorders ranks first in eye disease. Refraction abnormalities from year to year continue to increase. Found the number of people with refractive disorders in Indonesia, almost $25 \%$ of the population or around 55 million people. [1] The eye has a variety of refractive disorders such as myopia, hypermetropia, astigmatism, and presbyopia. [2]

Myopia is one of the highest prevalence of eye refractive disorders in the world. In observations over the past few decades, the average prevalence of myopia has increased and there is epidemiology of myopia in Asia. [3] Myopia or nearsightedness is a refractive damage to the eye where the shadows produced are in front of the retina when accommodation is relaxed. Myopia can occur because the eyeball is too long or because the curvature of the cornea is too large so that the incoming light is out of focus and the distant object appears blurred. Genetic, environmental, and lifestyle factors are risk factors that play an important role in the occurrence of myopia. [4] The prevalence of myopia in children with both parents myopia is $32.9 \%$ and reduced by 2 to $18.2 \%$ in children with only one of their parents experiencing myopia, and less than $8.3 \%$ in children with parents without myopia. [4] Lifestyle factors such as the habit of doing activities in close quarters including reading, using 
computers, cellphones, and playing video games have a big role against the occurrence of myopia. [4]

In addition to the above factors, food intake is also thought to have a role in increasing the incidence of myopia. Although there are no studies that clearly and directly state the relationship between dietary factors and myopia, it can be seen that people who have a diet with low vitamin and mineral content experience a greater incidence of myopia than people who consume foods containing vitamins and minerals. sufficient. In addition, adequate protein and other nutrients are thought to be able to slow the progression of myopia in children. [5] Based on the background above, the researchers wanted to conduct a study of risk factors for myopia in middle school students in Denpasar.

\section{Method}

\subsection{Population and Samples}

This research took place at St. Joseph's Middle School in Denpasar, Denpasar 7th Middle School, and 4th Junior High School Denpasar in November to December 2017. This analytical study conducted with a case control design, to determine the risk factors for myopia in middle school students in Denpasar. The case was students who use myopia glasses and have a visual examination. Control is students from the same school without myopia.The target population in this study were junior high school students in Denpasar and affordable populations were SMP 4, SMP 7, and SMP Yoseph Denpasar which were selected using cluster random sampling. Number of samples Samples that met the inclusion criteria were selected using a simple random sampling technique with a total of 108 people.

\subsection{Data collection}

The independent variable in this study is the risk factor for myopia, and the dependent variable of this study is myopia. Data was collected through direct interviews with middle school students according to the questionnaire. Data were analyzed by bivariate test and chi square test to find the relationship between independent variables and dependent variables.

\section{Results And Discussion}

Total 98 subject was recuited as samples divided to 49 case and 49 control, the most of them was male on average age 14 years old. Based on the results of the analysis in table 1, family history of myopia has a statistically significant relationship to myopia in the case group $(p=0.013 ; \alpha<0.05)$. Students who have genetic factors have a risk of 3.1 times greater experience of myopia compared to samples that do not have genetic factors. Based on the analysis of table 1 , lifestyle has a statistically significant relationship to myopia in the case group ( $\mathrm{p}=0.02 ; \alpha<0.05)$. Students who have a bad lifestyle are 2.7 times more likely to experience myopia compared to a sample with a good lifestyle. The results of the analysis showed that there were significant relationships between vitamins A, C, D and E with myopia in case group $(p=0.039 ; \alpha<0.05)$. Samples in the bad category are 2.6 times more at risk of having myopia than those in the good category. 
Table 1. Characteristics of research respondents

\begin{tabular}{llllc}
\hline \multicolumn{1}{c}{ Characteristic } & \multicolumn{1}{c}{ Case (n) } & Control $(\mathbf{n}(\%)$ & OR & P \\
\hline Gender & & & & \\
Male & 29 & 25 & & \\
Female & 20 & 24 & & \\
Age mean (years) & 14 & 14 & 3,130 & 0,013 \\
Family history of myopia & $36(73.5)$ & $23(46.9)$ & 2.729 & 0.026 \\
Life style & & & & \\
Good & $20(40,8)$ & $32(65,3)$ & & \\
Poor & $29(59,2)$ & $17(34,7)$ & & \\
Vitamin A,C,D,E intake & & & & \\
Good & $24(49,0)$ & $35(71,4)$ & & \\
Poor & $25(51,0)$ & $14(28,6)$ & & \\
\hline
\end{tabular}

Genetic Relations with Myopia The results of the study showed that in the case group $26.5 \%$ had genetic factors and $73.5 \%$ did not have genetic factors. In the control group $53.1 \%$ had good genetic factors while $46.9 \%$ were in the bad category. The statistical test results showed a significant relationship between genetic factors and the incidence of myopia $(\mathrm{p}=$ $0.013 ; \alpha<0.05$ ). Also obtained OR value $=3.130$ which means that samples with bad genetic factors have a risk of myopia of 3.1 times greater suffering from myopia compared to samples with good genetic factors. These results are not in line with the research from Widodo regarding the relationship between parental status or offspring with juvenile myopia degrees [6], there was no relationship between parental status or offspring with juvenile myopia degrees. [6] Other studies have shown the prevalence of myopia in children of both parents myopia is $33 \%-60 \%$ [7], whereas in children who have one parent with myopia the prevalence is as big as $23 \%-40 \%$. [8] Relationship between Lifestyle and Myopia Results showed that in the case group $40.8 \%$ had a good lifestyle while $59.2 \%$ were in the bad category. The control group $65.3 \%$ had a good lifestyle and $34.7 \%$ with a bad lifestyle. This can be seen from the results of statistical tests which showed a significant relationship between lifestyle and the incidence of myopia values $(\mathrm{p}=0.026 ; \alpha<0.05)$. A bad lifestyle has 2.7 times the risk of suffering from myopia compared to a good lifestyle (OR =2,729).

The results of this study are in line with the study of Launardo, it can be seen that there is a significant difference between the frequency of refractive abnormalities in the group with the habit of watching short distances with groups without close viewing habits, namely the incidence of refractive abnormalities higher in groups with close viewing habits $(p=0.003)$. [1] From other studies mentioning the relationship between distance reading and juvenile myopia degrees obtained $\mathrm{p}$ value $=0.042$. Because $\mathrm{p}(0,042) ; \alpha<(0,05)$ then Ho is rejected.[9] Then there is a relationship between reading distance with the degree of myopia adolescents.[10] According to the OR value, if you read closely it will increase 0.2 times the diopters of myopia adolescents compared to those who read with enough distance $(\geq 30 \mathrm{~cm})$. [7] Research on the use of gadgets explains the relationship between the intensity of the use of gadgets in one use and the degree of juvenile myopia obtained $p$ value $=0.049$. Because $p$ $(0,049) ; \alpha<(0.05)$ then Ho is rejected or there is a relationship between the use of gadgets in one use and the degree of myopia in adolescence. According to OR values, teens who use gadgets $>4$ hours risk having an increase in myopia diopters 3.57 times than those who don't use gadgets $>4$ hours. [7]

Based on the results of the study in the case group $49.0 \%$ consumed vitamins A, C, D and $\mathrm{E}$ in the good category while $51.0 \%$ in the bad category. The control group $71.4 \%$ consumed 
vitamins A, C, D and E in the good category and $28.6 \%$ in the bad category. Statistical tests show that research on vitamins $\mathrm{A}, \mathrm{C}, \mathrm{D}$ and $\mathrm{E}$ has a significant relationship to myopia with a value of $\mathrm{p}=0.039$ and with an $\mathrm{OR}=2.604$. Those who consume less vitamins $\mathrm{A}, \mathrm{C}, \mathrm{D}$ and $\mathrm{E}$ with a bad category have a risk of 2.6 times suffering from myopia compared to the good category. Based on the results of this study in line with the results of research Yustina said that vitamins $\mathrm{A}, \mathrm{C}, \mathrm{D}$, and $\mathrm{E}$ affect eye health. [5,11] In contrast to the results of this study, the results of data analysis from Anisa S \& Dyah Y explained the relationship between vitamin A intake and myopia in adolescents, the value of $p=0.519$. [7,12] Because $(p=0.519 ; \alpha<0.05)$ then Ho is accepted. The conclusion is that there is no relationship between vitamin A intake and juvenile myopia. This difference in results is due to not the same method of calculating vitamin intake in the study.

\section{Conclusions}

Based on the results of the study it can be concluded. There is a meaningful relationship between genetic factors and myopia in middle school students in Denpasar. There is a significant relationship between lifestyle and myopia in middle school students in Denpasar. There is a meaningful relationship between vitamins A, C, D and E with myopia in middle school students in Denpasar.

\section{References}

[1] James B, Chew C and Bron A. 2011. Lecture Notes on Ophtalmology 11st New York: Blackwell Publishing, 20-26.

[2] Iilyas S, Yulianti R. 2014. Ikhtisar Ilmu Penyakit Mata. Jakarta: Fakultas Kedokteran Universitas Indonesia.

[3] Fauziah M., Hidayat M., Julizar. 2014. Hubungan Lama Aktivitas Membaca dengan Derajat Miopia pada Mahasiswa Pendidikan Dokter FK Unand Angkatan 2010 (Jurnal Kesehatan Andalas). Padang: Fakultas Kedokteran Universitas Andalas.

[4] Komariah C, dan Wahyu N. 2014. Hubungan Status Refraksi, dengan Kebiasaan Membaca, Aktivitas di Depan Komputer, dan Status Refraksi Orang Tua pada Anak Usia Sekolah Dasar.

[5] Elisa, Yustina. 2015. Faktor Risiko Miopia pada Mahasiswa Fakultas Kedokteran Universitas Diponegoro Angkatan 2011-2014. Semarang: Fakultas Kedokteran Universitas Diponegoro.

[6] Agung W, Aprillia T. 2007. Miopia Patologi. Jurnal Oftalmologi Indonesia Vol 5:19-26.

[7] Anisa S, Dyah Y. 2016. Faktor-faktor Yang Mempengaruhi Derajat Miopia pada Remaja. Semarang: Jurusan Ilmu Kesehatan Masyarakat, Fakultas Ilmu Keolahragaan, Universitas Negeri Semarang, Indonesia.

[8] Wu L, Wang Y, You Q, Duan J, Luo Y, Liu L, et al. 2012. Risk Factors of Myopic Shift among Primary School Children in Beijing, China : A Prospective Study. International Journal of Medical Sciences. Vol 12(8): 633-638.

[9] Saxena R, Vashist P, Tandon R, Pandey RM, Bhardawaj. 2015. A. Prevalence of Myopia and Its Risk Factors in Urban School Children in Delhi : The North India Myopia Study. Plos One. Vol 1-11.

[10] Uchenna C. Atowa, Alvin J. Munsamy, Samuel O. Wajuihian. 2015. Prevalence and risk factors for myopia among school children in Aba , Nigeria. African Vision and Eye Health Vol 76(1):1-5. 
[11] Pan C, Wu R, Li J, Zhong H. 2018. Low prevalence of myopia among school children in rural China. BMC Ophthalmology Vol. 18(140): 1-6.

[12] Theophanous C, Modjtahedi BS, Batech M, Marlin DS, Luong TQ, Fong DS. 2018. Myopia prevalence and risk factors in children. Clinical Ophthalmology. Vol 12:1581-1587. 